\title{
Proposals for School Administration's Role in Solving Student Problems among Bedouin Schools within the Green Line, Israel
}

\author{
Dr. Laila Khaled Badarna \\ Psychologist in Awartt Comprehensive School, Bedouin Sector \\ Green Line, Israel
}

Dr. Muhammad Heib

National Director of Bedouin Education, Israel

\begin{abstract}
Received: July 14, 2016 Accepted: August 12, 2016 Published: September 04, 2016
doi:10.5296/ijld.v6i3.9979 URL: http://dx.doi.org/10.5296/ ijld.v6i3.9979
\end{abstract}

\begin{abstract}
The current study seeks to provide proposals for school administration; which in turn help overcome students' problems among Bedouin Schools. The sample consists of (50) of students' parents, teachers, and members of local society, intentionally selected. The instrument utilized in this study is the interview that used to collect data. The results showed that there are (16) proposals contributing to overcoming students' problems among Bedouin Schools within the Green Line; more than (50\%) of the participants were consistent with these proposals. The study concluded with several recommendations, most notably: The need to activate school administration role in overcoming and reducing students' problems for the negative effects they have upon the school and community.
\end{abstract}

Keywords: School administration, Students' problems, Schools of the Bedouin society 


\section{Introduction}

The school administration is considered one of the most important areas of administration and the greatest one in the community, whose role is no longer limited to implement educational policies and objectives but has become responsible for raising the generations and qualifying them in a rapidly changing era. School administration keeps in direct contact with the community, provides it with care and education, and proper environment that would academically qualify students well, leading eventually to the progress of community and upgrades its level.

Consequently, the school administration is essential in helping students grow well in all areas to become good citizens and responsible for themselves and their home countries (Zahran, 2012). The importance of the school administration lies in the influence and change made in the students' behaviors through behaving in several aspects like belief in the objectives of the school, the willingness to work for the school and being proud of it and willing to stay in it (Hulpia and Devos, 2009). The school administration continuously follows up the students' issues and problems, monitors and provides solutions (Faulkner, 2015).

School leadership should have its goals and distinctive attitudes, every active administrative employee from the director of the educational administration to the educational system should know the intended and great aim of the task he does, so the educators concluded that the school leadership is a set of views, ideas, trends, and human activities; that clarifies goals, makes plans and programs, organizes the organizational structures, creates administrative jobs and bodies that practice implementation, training, monitoring, and evaluation (Al-Bakri, 2005).

Effectiveness and success of leadership manifested clearly in the situations that make harmony between the situation requirements and leadership style necessary for the situation, and personal characteristics of the leader, that the leadership style of a situation is effective to the extent that the leader is empowered to achieve goals for which the leadership position is allocated (Anastasia \& Angeliki, 2008)

Consequently, the administrator is responsible for examining his group, their roles, consolidation, goals, and their structure, and he has to influence the behavior of the group and direct its members to achieve its goals (Faulkner, 2015).

In this regard, a global attention was given to make studies that research on the leadership behavior of the principal, as he is an educational leader, and the influence of this behavior on the organizational changes related to the success of the school, effectiveness of the institution and its goals, accepting its role, solving its problems, achieving satisfaction and morale of its employees, and developing the human relations (Al-Beblawy \& Abdul-Hamid, 2004).

The method that the school administration managed is considered the backbone of the effective role of the school towards the community addressing values crisis and helping students grow well in all areas to become good citizens and responsible for themselves and their home countries (Zahran, 2012). 


\section{Macrothink}

The schools all over the world have recently suffered from academic and behavioral problems that urgently called for solving. These problems have become a major barrier in achieving the school's ultimate goal which is to provide school with the needs of students, teachers and employees. The school administration has an important role as it represents the educational leadership within the school (Hulpia and Devos, 2009).

In the light of the point of the current study that deals with the students' problem, literature review that conducted on the students' problem field has been revised, and the author of the current study noted that it confirmed the spread of the students' problems differed in its degree and quality, in this regard Al-Beladi (2010) confirmed that the most common problems among high school female students are cheating and imitating men. Al-Athamna (2003) also showed that the most common problems that high school students suffer from are straying, distraction, lack of concentration, revolt behavior, hyperactivity, shyness, social withdrawal and aggressive behavior. Ibrahim (2004) assured that the most important school problems from which the students suffer are aggressive and psychological problems, rebellion, and the loss of belonging to the community. Jamil (2007) found that the most important behavioral problems among students according to their teachers' perspective are rush and neglect of the study, the lack of attention, low academic achievement. Cryer (2009) showed that the problem of lying is one of the most common behavioral problems among students.

Several pieces of literature review and studies assured the importance of the role of school administration to solve the students' various problems that confront students in different academic stages, including (Al-Jadi, 2008), (Al-Sharari, 2008), (Adawy, 2008), (Adwan, 2010), (Zaki and Khatab, 2012), (Al-Shehab, 2013), (Al-Hamdanah, 2014), while other studies showed the importance of the administrative style to reduce the students' problems such as Al-Rashidy (2010) which showed that the democratic pattern reduces the students' problems and school violence. Monty (2003) found that the treatment method based on guidance and direction, reinforcements, and education through collective classroom interaction is the best method to treat the students' behavioral and academic problems. While the study of Al-Jadi (2008) assured the importance of the community partnership with school administration to solve school and students' problems.

\section{Statement of the Problem}

Joint National Committee between Ministries (2015) indicated that the students' problems have recently spread in schools, including academic, emotional, and behavioral problems.

Hence, the author conducted this study to provide proposals about the role of school administration in solving students' problems in the Bedouin schools within the Green Line. The problem of the present study emerged in answering the following question:

1- What are the methods suggested by parents, teachers, and local community institutions to solve students' problems in the Bedouin schools within the Green Line? 


\section{Significance}

The importance of this study lies in the following:

- The current study adds new information to the human knowledge about the role of school administration in solving student problems, and the proposals of the study are to improve the role of school administration in solving student problems in the Bedouin schools within the Green Line.

- Identifying the students' problems and the role of school administration in solving them, which in turn contributes to offering effective solutions for student problems in the future.

- Educational leaders and principals may benefit from the results of the field study to activate the role of school administration in solving students' problems and applying them to the local educational field in the Bedouin community within the Green Line.

- Study's results may help principals be aware of activating their roles in solving students' problems through practical and applied proposals offered by schools' employees, parents, and local community in the Bedouin community within the Green Line.

\section{Sample}

To achieve the study goals, and answering the study instrument (interview), the sample intentionally selected, and consisted of (50) participants, (20) of them are students' parents, (15) are teachers in the Bedouin schools within the Green Line, (15) are of the local community.

\section{Instrument: Interview}

The interview based on a set of questions prepared in advance, questions were changed in arrangement according to course of the interview, and information were given, which made the author feel free to ask questions in many forms, and pave the way for the responder to give more clarification. (Abu-Zeina, et al, 2007)

The author of the current study made interviews with (50) participants, (20) of them are students' parents, (15) teachers in the Bedouin schools within the Green Line, (15) participants from the local community. The interview designed to collect data about identifying the proposals and solutions that contribute to overcoming students' problems among Bedouin Schools. The answers were recorded focusing on writing the answers as said by the responder, leaving the interpretation after the interview.

The interview questions were formulated to cover all students' problems and suggested solutions to overcome students' problems among Bedouin Schools within the Green Line, there are (2) questions presented to a group of referees to know their opinion to be taken into consideration. 


\subsection{Validity}

To verify the validity of the interview, the author formulated a set of sub questions, which were evaluated by a group of reviewers, to check the number of questions, arrangement, language, and the appropriateness of the questions, and their ability to achieve the study objectives. The reviewers advised linguistic modification, and confirmed that the instrument is valid to achieve the goals of the study. This indicated the validity of the instrument.

\subsection{Reliability}

To verify the reliability of the interview; correction reliability was used, where a number of interviews were conducted with (6) principals: ( 3 males and 3 females) about the role of the school administration in solving students' problems, and the ways and methods to overcome these problems. After responding, the author calculated the frequencies; and to verify the reliability, the author wrote down the answers of the six principals (the pilot sample), analyzed its content by writing it and transcribing it in a special form. After two weeks, the interviews were re-conducted again, two weeks after the first interview, on the same sample. The reliability coefficient was $(0.85 \%)$ - it is considered appropriate value for achieving the objectives of the study, as its known that the appropriate reliability coefficient used in analyzing the content must be more than $(0.80)$.

\section{Results}

Results related to the answer of the question: What are the methods suggested by parents, teachers, and local community institutions to solve students' problems in the Bedouin schools within the Green Line? To answer this question, the responses of the interviews were analyzed, frequencies and percentages for the responses of the participants calculated. The participants pointed to the suggested solutions and the ways that help overcome the student problems in the Bedouin schools within the Green Line, as shown in the following table.

Table (1): Frequencies and percentages for the ways that help overcome the student problems in the Bedouin schools within the Green Line from the parents, teachers, and local community institutions' perspective, $\mathrm{N}=(50)$

\begin{tabular}{|l|l|l|l|}
\hline No. & Proposal & Frequency & Percentage \\
\hline 1. & $\begin{array}{l}\text { Finding communication means between school } \\
\text { administration and students families to know the } \\
\text { behavior of the student in the school. }\end{array}$ & $\mathbf{9 0 \%}$ \\
\hline 2. & $\begin{array}{l}\text { Students training on the life skills, by providing } \\
\text { psychological counseling services and programs } \\
\text { compatible with the nature of the people of Bedouin } \\
\text { community and focusing on their needs. }\end{array}$ & $\mathbf{9 0 \%}$ \\
\hline 3. & $\begin{array}{l}\text { Identifying appropriate preventive programs for } \\
\text { 2. }\end{array}$ & 84 & $88 \%$ \\
\hline
\end{tabular}




\begin{tabular}{|c|c|c|c|}
\hline & students' problems. & & \\
\hline 4. & $\begin{array}{l}\text { Finding effective system for communicating with the } \\
\text { families and parents of the students to solve students' } \\
\text { problems. }\end{array}$ & 43 & $86 \%$ \\
\hline 5. & $\begin{array}{l}\text { Engage students in interesting activities acquiring him } \\
\text { different experiences such as journeys and sports. }\end{array}$ & 41 & $82 \%$ \\
\hline 6. & $\begin{array}{l}\text { School administration adopts interactive relationships } \\
\text { with society, which in turn contribute to integration } \\
\text { between students and collective activities, and get them } \\
\text { accustomed to teamwork. }\end{array}$ & 39 & $78 \%$ \\
\hline 7. & $\begin{array}{l}\text { Providing emotional care by the school administration } \\
\text { through the cooperation with a team of medical } \\
\text { assistants (art and drama therapy). }\end{array}$ & 38 & $76 \%$ \\
\hline 8. & $\begin{array}{l}\text { Holding periodical meetings for training students on } \\
\text { dialogue and debates about their personal problems. }\end{array}$ & 36 & $72 \%$ \\
\hline 9. & $\begin{array}{l}\text { Meeting the needs of students by providing playgrounds } \\
\text { and labs. }\end{array}$ & 36 & $72 \%$ \\
\hline 10. & $\begin{array}{l}\text { Encouraging psychologists and drama therapists on } \\
\text { using methods of psychological counseling, including } \\
\text { playing, persuading, relaxing, reinforcement, and } \\
\text { determent. }\end{array}$ & 33 & $66 \%$ \\
\hline 11. & $\begin{array}{l}\text { Support with local community in Bedouin society to } \\
\text { carry out the extracurricular activities within the needs } \\
\text { of this community to reduce the students' problems. }\end{array}$ & 31 & $62 \%$ \\
\hline 12. & $\begin{array}{l}\text { Identifying and focusing on students with special } \\
\text { problems, because they are more vulnerable to } \\
\text { behavioral disorders and deviations. }\end{array}$ & 30 & $60 \%$ \\
\hline 13. & $\begin{array}{l}\text { Regulate clear system to the students to familiarize } \\
\text { them with the bad results of academic, emotional, } \\
\text { social, or behavioral problems. }\end{array}$ & 29 & $58 \%$ \\
\hline 14. & $\begin{array}{l}\text { Focus on weak-personality students; because they are } \\
\text { more likely to persuading, and more likely to be }\end{array}$ & 28 & $56 \%$ \\
\hline
\end{tabular}




\begin{tabular}{|l|l|l|l|}
\hline & affected by the bad companion. & & $52 \%$ \\
\hline 15. & $\begin{array}{l}\text { Holding remedial classrooms to develop the student } \\
\text { ability based on using certain devices to deliver } \\
\text { information to the students with academic problems. }\end{array}$ & 27 & $50 \%$ \\
\hline 16. & $\begin{array}{l}\text { The school employees and parents are to be aware of } \\
\text { the available treatment ways for these problems, and } \\
\text { identifying the role of each one. }\end{array}$ & 25 & \\
\hline
\end{tabular}

Table (1) showed that there are (16) proposals that help overcome the student problems in the Bedouin schools within the Green Line from the parents', teachers', and local community institutions' perspective, where $(50 \%)$ of the study sample were consistent with these proposals.

\section{Discussion}

Results showed that the study sample (the participants) recommended a set of proposals that help overcome the student problems in the Bedouin schools within the Green Line; such proposals may result in practical benefits in the school, that may benefit the educators (principle, teacher, student advisor and psychologist) in developing programs and strategies that match with these proposals for preventing, treating, or reducing students' problems.

Based on the proposals with which the study concluded, which contribute to the role of school administration in overcoming the students' problems in Bedouin schools within the Green Line, it is hoped that the principals do great efforts to address the students' problems. In addition, the principle is responsible for developing guiding programs designed to prevail positive values and behaviors among students, and facing negative values and behaviors, these programs encourage them and make them feel they are responsible for keeping security and safety within the school environment, and spreading this feeling among all students irrespective of their various classes and levels of study.

The current results are consistent with Al-Jaidy (2014), which showed the need of the school administration to adopt a set of policies and proposals to reduce the students' problems such as activating partnership between school, local community and school administration for cooperation with local community.

\section{Recommendations}

In light of the results of the current study, the following recommendations have been made:

- Organizing of training courses about how to deal with students' problems, which should be attended by principals, teachers, academic advisors, psychologists and drama therapists.

- Developing guiding programs addressing students to modify their behaviors and inform them about the negative effects of academic, emotional, social, and behavioral problems on students and community. 
- The need to activate the role of the school administration in solving the students' problems through utilizing the proposals made by the respondents in drawing the attention of the school administration in the Bedouin schools within the Green Line to solve students' problems and reduce them for the dangers that threaten the school environment and the community.

- Qualitative future studies can be conducted about school administration strategies in solving the students' problems, and overcoming them, in the Bedouin schools.

\section{References}

Ibrahim, Ahmed. (2007). Comparison of the problems of high school students: with and without father (due to travelling). Unpublished MA Thesis. Egypt: Cairo, Ain Shams University.

Abu-Zeina, Farid, Al-Ibrahim, Marwan, Kandilgy, Amer, Addass, Abdu- Alrahman, Alyaan, Khalil. (2207). Methods of research: methods of qualitative research, (2). Oman: Dar AlMasyra.

Al-Beblawy, Ihab, Abdu-Alhamid, Ashraf (2004). Psychological Consulting and Direction: Strategy of the work of psychologist in normal and disabled schools. Al-Riyadh: Dar AlZahraa for publication and distributing.

Al-Bakri, El Mogahid (2005). The influence of the leadership on job loyalty in educational sector. Egypt: Nahdah Egyptian library.

Al-Beladi, Mona. (2010). Some behavioral problems among high school female students and treatment in the light of Islamic education. Unpublished MA Thesis. Saudi Arabia: Makkah, Umm Al Qura University.

Al-Jadi, A. (2008). The role of the school administration in the treatment of high school female students' problems in Gaza Governorates and ways of its activation, Unpublished Master Thesis. Palestine: Gaza, the Islamic University.

Al-Jaidi, Sheikha. (2014). The role of school administration in the activation of community partnership between high schools for girls and the community. Arab Gulf Journal, (132), p. 189.

Jamil, Muhammad. (2007). Behavioral problems of elementary school students in Makkah. Journal of Education at King Abdul Aziz University, (1), 50 - 82.

Hamadna, Muhammad. (2014). The role of school administration in reducing the phenomenon of violence in Jordanian schools. International Specialized Journal of Educational, 3 (7), 56 - 73.

Al-Rashidi, Eid (2012). Administration styles practiced by principals of secondary schools in the State of Kuwait and their relationship to the level of student violence from the teachers' perspective. Unpublished MA Thesis in Education, Faculty of Education, University of the 
Middle East, Amman, Jordan.

Zaki, Ahmed; Khattab, Muhammad. (2012). The role of school administration in addressing dropout in middle schools in Ihsa. Journal of Specific Education Research, 24 (2): 733-760.

Zahran, Iman. (2012). The role of school administration in facing the crisis of values among $2^{\text {nd }}$-stage elementary students in light of the twentieth century variables. The $11^{\text {th }}$ Scientific Conference, Egypt, May 29 - 30, pp. 15-17.

Al-Sharari, Khaled. (2008). The role of principals in the face of the phenomenon of violence among secondary school students. Unpublished MA Thesis, Yarmouk University, Irbid, Jordan.

Shehab, Scheherazade. (2013). The effective role of the principal to curb the phenomenon of willingness to commit suicide from the perspective of students. Journal of College of Elementary Education Research, 12 (4): 25-51.

Al-Athamna, Abdul-Latif. (2003). The level of behavioral problems among secondary school students in public schools and the difficulties of dealing with them from the perspective of educational advisers in the provinces of the north of Palestine, unpublished Master Thesis, An-Najah National University, Nablus, Palestine.

Adwan, Susan. (2010). Student behavioral problems faced by principals of private schools and proposals to address them in Jordan. Unpublished MA Thesis, Amman University, Amman, Jordan.

Adawy, Osama. (2008). The role of principals to reduce the phenomenon of violence among high school students in the provinces of Gaza and ways to activate this role from the teachers' perspective. Unpublished MA Thesis, Islamic University of Gaza.

Joint National Committee between Ministries. (2015). A national program for children and youth at risk.

Anastasia, A.R. and Angeliki, L. (2008). Requirements, Roles, and Challenges of the Principalship in Greece and Cyprus. European Education, 40(3): 65-88.

Cryer, J. (2009). How do Beginning Administrators Navigate Through Their First Year of the Middle School Principalship? ProQuest LLC. Ed.D. Dissertation, University of Northern Lowa.

Faulkner, C. (2015). Women's Experiences of Principalship in two South African high Schools in Multiply Deprived rural areas: A life history Approach. Educational Management Administration \& Leadership, 43(3): 418-432.

Fridman, K., ( 2003). Adolescent Psychiatry. New York, Pocket Books.

Hulpia, H, and Deevos, G. (2009). The Influence of Distributed Leadership on Teachers Organizational Loyalty. Journal of Educational Research, 103 (1): 40-52.

Monty, J. (2003). School-wide Discipline in Urban High Schools: Perceptions of Violence 


\section{Macrothink}

International Journal of Learning and Development

ISSN 2164-4063 2016, Vol. 6, No. 3

Prevention Strategies. Dissertation Abstracts International, 62-11A, AA13033978: 3652-3670.

\section{Copyright Disclaimer}

Copyright for this article is retained by the author(s), with first publication rights granted to the journal.

This is an open-access article distributed under the terms and conditions of the Creative Commons Attribution license (http://creativecommons.org/licenses/by/3.0/). 